\title{
Transforming traditional communicative language instruction into computer- technology based instruction: experiences, challenges and considerations.
}

\author{
Experiencias, retos y puntos para tener en cuenta \\ en la transición entre un enfoque comunicativo de \\ enseñanza del inglés como lengua extranjera a un \\ enfoque mediado por el uso de las TICS.
}

Héctor Alejandro Galvis ${ }^{1}$

\section{Abstract}

This paper serves as a report on a qualitative study that was conducted in a language center in Colombia, with the aim of exploring the integration of computer technology into two EFL classes. This process involved the transformation of a traditional communicative language syllabus into a computer-technology oriented one which included the use of virtual communities, E-mail, Blogs and an instant-messaging application. Results of this study led to a critical discussion of the role of teachers and institutions when implementing computer technology. Other findings of this study suggest that some of the participants tended to choose computer-mediated communication over face-to-face interaction when communicating in EFL. It could also be observed that the participants expressed their willingness to continue using computer technology in future language instruction.

\section{Key words}

Teaching adolescents EFL, teaching English and technology, computer-mediated communication, role of institutions in the use of computer technology.

\section{Resumen}

Este artículo reporta una investigación de tipo cualitativo que se realizó en un centro de enseñanza del inglés en Colombia y cuyo objetivo fue explorar la implementación de la tecnología en dos clases de enseñanza del inglés como lengua extranjera. Este proceso se llevo a cabo por medio de modificaciones curriculares que llevaron a la inclusión de correo electrónico, foros de discusiones y aplicaciones de mensajería instantánea como medios para facilitar proyectos en el aula. Los resultados llevan a replantear el rol de docentes e instituciones para contribuir a la integración de las TIC cuando estas han sido excluidas curricularmente. De la misma manera, los resultados sugieren que algunos participantes preferirían seguir utilizando tecnología, y comunicarse por medios electrónicos en lengua extranjera en lugar de sostener conversaciones vis-à-vis entre sus compañeros de clase.

\section{Palabras clave}

Enseñanza del inglés a adolescentes, enseñanza del inglés y uso de tecnología, comunicación mediada por computador, responsabilidad de las instituciones respecto al uso de la tecnología.

Artículo recibido el 10 de noviembre de 2010 y aprobado el 19 de agosto de 2011

1 Profesor de la Universidad Pedagógica Nacional. Correo electrónico: alejandro.galvis.hg@gmail.com 


\section{Introduction}

Computer technology in language education is perceived as a promising language learning tool due to the versatility, flexibility and adaptability that each individual enjoys when approaching computer applications. In fact, Chapelle (2003) states that computers represent a great potential for the facilitation of language input because of the ability to integrate multimedia material such as videos, images and text simultaneously into one single screen. Furthermore, Butler-Pascoe and Wiburg (2003) argue that the use of computer technology facilitates interaction and presents language in an enhanced manner making it different from the language traditionally presented in textbooks as argued by Chapelle. While all of the reasons above may represent significant advantages for traditional instruction vs. technology-based instruction in language learning, it is also of utmost importance to bear in mind that both the use of computer technology has been associated with both disinhibiting students and lowering anxiety (Roed, 2003). These innovative characteristics of the use of computer technology are said to be motivated by the fact that students' output usually reaches a real audience as it simultaneously allows individuals to reflect on their language output, before such output is actually produced, something that face-to-face interaction may not necessarily allow for.

Based on the premises above, a qualitative study was conducted with the cooperation of the directors of an English language center in Colombia. The main purpose of this study was to explore the behavior and attitudes students display when switching from a traditional communicative type of language instruction to one based on technology and the use of the Internet. This paper consists of five sections. In the first section, a brief theoretical framework that supports the use of computer technology in the classroom will be presented, in addition to some considerations regarding teaching adolescents; the second section will provide a description of the research design and details where this study was conducted. Section three will include the findings of the data collection followed by section four in which the implications of the results will be dis- cussed. Finally, section five will include suggestions for further research.

\section{Computer technology in language learning}

The introduction of computer technology in language education and its recent new inherent companion, namely, the Internet has been described in academic literature to be a potential tool in language learning. The history of computer-technology in education seems to be best put in a nutshell by Warschauer and Healey (1998) in which one can see how computer software patterns have followed the same philosophies and principles of evolving language teaching approaches and methodologies moving from the classical behaviorist approaches and methods to more communicative ones. For example, one can see that incurrent language teaching approaches such as the Task Based Learning (TBL) and Content-Based Instruction (CBI) framework, the target language is no longer an object of study, rather a medium for communication, negotiation of meaning, and most recently, a medium for negotiation of identity (Norton Pierce, 2000).

Bearing the above in mind, computer technology and the Internet seem to match perfectly the current trends and needs, not only for language education but also the dynamics of the current world in which flexibility, efficiency and versatility are highly favored if not constantly demanded from individuals in different domains. With no surprise, one finds that computer technology has been even proposed to be a perfect match for these dynamics. An example of how computer technology fulfills these needs is presented by Butler-Pascoe and Wiburg (2003) who explain that computer technology matches the TBL framework in that students and teachers can benefit from having direct access to real audiences synchronously or asynchronously, getting involved in problem-solving activities, and being in contact with authentic language.

Similarly, Chapelle (2003) argues that the potential of computer technology for language learning resides in the type of input modification and enhancement that can be brought about by tasks as simple as presenting a text accompanied by a pic- 
ture, the saliency that can be generated by the use of hypertext and graphic modification, or simply a handy instantaneous translation in the students' $\mathrm{L} 1$ on the screen. Furthermore, Chapelle explains how intrapersonal communication, that is, the type of communication between human beings and their internal voices, can happen in synchronous communication over the Internet (e.g. chatrooms) and how such type of interaction might lead to better language acquisition due to the window of opportunity learners have to reflect on language output, its accuracy and the motivation of interacting in real life with another interlocutor.

\section{Teaching adolescents}

Adolescence is a developmental stage comprised of crucial physical, psychological and cognitive changes that will shape up individuals for adulthood. Among these changes, several emotional fluctuations are commonplace and influence various constructs, one of them being motivation. Changes caused by adolescence are not necessarily negative, however, as explained by Lerner, Easterbrooks, Mistry and Weiner (2003) the combination of other factors such as self-efficacy, self-esteem, self-concept, and identity among many others can impact positively or negatively the overall regulations of emotions.

It appears that all of the changes adolescents experience have transferred to education making teaching adolescents a challenge. In light of this, Reed, Scharllert, Beth and Woodruff (2004) point out that traditional forms of teaching, particularly, teaching literacy are not adolescents' preference, and that their motivation may be found in alternative forms that teachers and parents are not considering such as instant-messaging on the Internet. Regarding instant-messaging, Reed et al. (2004) state that instant messaging is an unexplored literacy alternative that may represent a better path to educating adolescents based on a fourfold combination of the following factors: freedom of choice, control support, sense of competence and the need to communicate with others.
By the same token, Wolsey and Grisham (2007) specifically report on the benefits of computer technology in education when a group of eight graders in a school in California used asynchronous tools online and obtained better motivation and engagement in writing as well as a rate of more elaborated responses when interacting with their instructors online. Among other considerations, Wolsey and Grisham, from their study, concluded that there may be a gap between the type of instruction imposed by teachers and the type of new literacies preferred by students.

\section{Research Design}

\section{Setting}

The language center where this study was conducted is located in Bogotá, Colombia. This language center offers various EFL programs, one of them being designed for children, adolescents and individuals who seek extra instruction in English in order to perform better academically in the different schools they attend during weekdays. The envisioned exit profile for each student enrolled is to be an intercultural and communicative competent individual who can use the English language for various everyday purposes. Students enrolled in this language center take two hours of English on weekends. Each level lasts an academic semester making up for a total of twelve levels.

\section{Participants}

This study was conducted during the fall 2006 semester. Two in-service teachers participated in this study; each teacher was responsible for four classes during the day. From these four classes, each teacher chose one of their classes in a way that was compatible in terms of the schedule and level of proficiency as that of the other teacher's. The chosen classes consisted of a total of 28 students, 13 were part of class $A$, and 15 were part of class $\mathrm{B}$ respectively. Both classes were co-educational, with students from different socio-economic backgrounds. No particular attention was given to gender distribution or attitudes in each class. 


\section{Data collection}

Data was obtained by means of written open-ended surveys, questionnaires as well as teachers' field notes. The surveys and questionnaires used in this study were administered at different times during a period of one semester. The questionnaires used at the beginning of the study served to explore how familiar the target population was with the use of common Internet applications, and how feasible it was for this population to use such applications outside the classroom. Similarly, some surveys were administered to students, but these surveys were not exploratory, rather they attempted to tap into the different reactions students had once they finished using any of the technology-based language tasks proposed. Toward the end of the semester, students were administered a questionnaire. This questionnaire was inspired by The Attitude/Motivation Test Battery proposed by Gardner (1985), nevertheless, the structure and the questions were adapted to the particular needs of this study. Other research instruments such as field notes were used throughout the study; these field notes were taken every time the two classes performed an Internet-oriented task. One teacher took field notes whereas the other provided linguistic and technological support to students.

\section{Findings}

Upon research completion, data-collection instruments were administered; these were analyzed and quantified. Close-ended questionnaires and surveys were quantified statistically, whereas open-ended surveys were categorized using the classical colorcoding technique in order to generate categories for interpretation. In the first exploratory survey, the following facts were found:

- The great majority of the students reported having access to a personal computer at home.

- Students reported being adept at using Internet applications such as chatting, E-mailing, or simply web-surfing. Likewise, students reported on being able to do activities online such as listening to music, playing video games among others.
- Students reported on having done some of the activities above in English as well as using their personal computer for school homework purposes.

- Students indicated that the use of their personal computer constituted a personal choice and not any imposition by parents or schools, although doing homework was a major reason to use a computer at home.

As shown above, the conditions appeared to be more than favorable for implementing computer technology in the selected classes because not only were most students familiar with the use of a computer and the Internet, but also they had had some experience using different applications. Despite the familiarity with some online applications, none of the students reported any previous use of virtual communities. This led the researcher to introduce the use of a virtual community popularly known as Yahoo 360. Once students created their personal space in Yahoo 360; a semi-structured survey was administered to evaluate their different reactions and perceptions. The results obtained from this survey are shown qualitatively in terms of perceptions and quantitatively in terms of willingness of students to use Yahoo 360, in the future (see Table 1).

\begin{tabular}{|ll|}
\hline Table 1. Students' perceptions after using Yahoo $\mathbf{3 6 0}$ \\
\hline Aspect analyzed & Students' perception \\
\hline Communication & $\begin{array}{l}\text { Yahoo } 360 \text { is a means of perso- } \\
\text { nal expression and communica- } \\
\text { tion with other classmates. }\end{array}$ \\
& Yahoo 360 allows to practice \\
Usefulness & English. \\
& Yahoo 360 is complicated and \\
nser-friendliness & not any different from other vir- \\
& tual communities. \\
Willingness for future use & $59 \%$ willingness for future use. \\
& $33 \%$ would avoid future use. \\
& $8 \%$ hold a neutral position. \\
\hline
\end{tabular}

As classes continued, a third technology-based task was introduced. In this task students were required to exchange information using a common instant-messaging client (MSN Messenger) in order to develop a pedagogical task, which required infor- 
mation seeking. Students had to exchange information with their peers from the other class by chatting in real time. After completing this task, students were administered one more survey. Their perceptions were summarized quantitatively in Table 2 :

\begin{tabular}{|l|l|}
\hline Table 2. Students' perceptions of using MSN Messenger \\
\hline Aspect analyzed & \multicolumn{1}{c|}{ Students' perception } \\
\hline Acceptability & $\begin{array}{l}57 \% \text { reported chatting easier than speaking vis-à-vis. 30\% would choose speaking vis-à-vis over chatting. 13\% } \\
\text { of students held a neutral position. Also, students found the use of MSN Messenger innovative. }\end{array}$ \\
Motivational factor & $\begin{array}{l}83 \% \text { reported MSN Messenger being motivating to chat in English, however, 13\% found face-to-face commu- } \\
\text { nication more motivating because it is easier. }\end{array}$ \\
Willingness for future use & $\begin{array}{l}100 \% \text { stated being willing to use MSN Messenger in future language instruction. Although some students } \\
\text { expressed their concerns for lack of prompt replies while interacting online. }\end{array}$ \\
\hline
\end{tabular}

Note: Acceptability was examined based on Chapelle's (2003) model of intrapersonal communication when engaged in computer-mediated interaction. It was the researcher's assumption that acceptability could be based on the ability for MSN messenger to disinhibit students by allowing more time to think of possible answers when chatting.

Finally, a fourth questionnaire was administered to students at the end of the course. By this time, students had been involved in other technologybased tasks that were not assessed by means of a survey or a questionnaire. As explained elsewhere, the final questionnaire was inspired by The Attitudel
Motivation Test Battery (Gardner, 1985). The first part of this questionnaire was adapted in order to analyze students' overall perception of their English classes and their reasons to study English. Some of the results in the first section of the questionnaire can be found in Table 3 .

Table 3. Students' overall perceptions of the English class

Respecto a tus clases de inglés este semestre

(Talking about your English classes this semester)

\begin{tabular}{|l|l|l|l|l|l|}
\hline Statement & $\begin{array}{l}\text { Fully } \\
\text { agree }\end{array}$ & $\begin{array}{l}\text { Partially } \\
\text { agree }\end{array}$ & Neutral & $\begin{array}{l}\text { Partially disa- } \\
\text { gree }\end{array}$ & $\begin{array}{l}\text { Fully } \\
\text { Disagree }\end{array}$ \\
\hline $\begin{array}{l}\text { Me encanta aprender inglés (I love to study the English } \\
\text { language). }\end{array}$ & $52 \%$ & $48 \%$ & & & \\
\hline $\begin{array}{l}\text { Me parece motivante aprender sobre el uso de herra- } \\
\text { mientas de Internet para aprender ingles (I find motiva- } \\
\text { ting to learn about Internet tools to learn the English } \\
\text { language). }\end{array}$ & $58 \%$ & $30 \%$ & $4 \%$ & $4 \%$ & $4 \%$ \\
\hline Necesito aprender inglés (I need to learn English). & $69 \%$ & $23 \%$ & $4 \%$ & $4 \%$ & \\
\hline
\end{tabular}


The remaining questionnaire items addressed the Internet tools used in both classes. The results of this section are presented in Table 4:

\begin{tabular}{|c|c|c|c|c|c|}
\hline Statement & $\begin{array}{l}\text { Fully } \\
\text { agree }\end{array}$ & $\begin{array}{l}\text { Partially } \\
\text { agree }\end{array}$ & Neutral & $\begin{array}{l}\text { Partially disa- } \\
\text { gree }\end{array}$ & $\begin{array}{l}\text { Fully } \\
\text { Disagree }\end{array}$ \\
\hline $\begin{array}{l}\text { Utilizar mi correo electrónico para comunicarme en inglés con } \\
\text { personas en el extranjero me motiva más a aprender inglés por- } \\
\text { que veo que es útil (I find E-mailing people abroad in English so- } \\
\text { mething motivating for me to continue learning English, because } \\
\text { I see English becomes useful). }\end{array}$ & $62 \%$ & $19 \%$ & $19 \%$ & & \\
\hline $\begin{array}{l}\text { Cuando chateo en inglés siento que tengo la oportunidad de ana- } \\
\text { lizar lo que digo en mi mente y después decirlo con seguridad } \\
\text { (When I chat In English, I feel I have the opportunity of reflecting } \\
\text { upon what I am going to say, and then say it assertively). }\end{array}$ & $82 \%$ & $11 \%$ & $7 \%$ & & \\
\hline $\begin{array}{l}\text { Quiero seguir usando Yahoo } 360 \text { el próximo semestre (I would } \\
\text { like to use Yahoo } 360 \text { during the next course). }\end{array}$ & $56 \%$ & $35 \%$ & $3 \%$ & $3 \%$ & $3 \%$ \\
\hline $\begin{array}{l}\text { Chatear con alguien del curso me parece mejor que hablar con } \\
\text { esta persona cara a cara (Chatting with a classmate seems a } \\
\text { better option than engaging in a face-to-face conversation. }\end{array}$ & $29 \%$ & $25 \%$ & $35 \%$ & $11 \%$ & \\
\hline
\end{tabular}

Finally, the third section of the questionnaire attempted to tap into students' final perceptions of the whole computer-technology integration. The results are presented in table 5:

\begin{tabular}{|l|l|l|l|l|l|}
\hline $\begin{array}{l}\text { Table 5. En términos generales } \\
\text { (Generally speaking) }\end{array}$ & Fully agree & $\begin{array}{l}\text { Partially } \\
\text { agree }\end{array}$ & Neutral & $\begin{array}{l}\text { Partially di- } \\
\text { sagree }\end{array}$ & $\begin{array}{l}\text { Fully } \\
\text { Disagree }\end{array}$ \\
\hline Statement & $30 \%$ & $7 \%$ & $4 \%$ & $4 \%$ \\
\hline $\begin{array}{l}\text { Ahora me gusta el inglés más que antes (I feel I like } \\
\text { English more than before). }\end{array}$ & $55 \%$ & & & & \\
\hline $\begin{array}{l}\text { Me gusta el inglés más que antes porque utilicé herra- } \\
\text { mientas de Internet y me parecieron divertidas (I used } \\
\text { Internet tools that were fun and this made me like English } \\
\text { more than before). }\end{array}$ & $41 \%$ & $37 \%$ & $11 \%$ & $7 \%$ & $4 \%$ \\
\hline
\end{tabular}

\section{Discussion}

Student perceptions and opinions analyzed regarding technological tools in English class demonstrated their willingness not only to simply use such tools, but also to use them when English served as a means for communication. Despite these results, it is worth pointing out that the center's lack of computer technology in the syllabus at the time represented a major challenge as much modification was necessary in order to turn such syllabus into an ad-hoc technology-based one while still maintaining the course's linguistic objectives. In fact, finding common ground between course objectives and students' likes and dislikes with the inclusion of technology was one of the most crucial challenges to overcome, without 
neglecting that the syllabus proposed by the center at the time seemed to be overfilled and gave no room for extra activities. Given these difficulties, the researcher addressed what appeared to be four main concerns that could lead to the envisioned implementation of computer technology. These concerns were as follows:

- Feasibility

- Time

- User-friendly interface

- Students' likes and dislikes

Feasibility was the first step to circumscribing the different alternatives one can find when referring to integrating technology in the language classroom. It is true that computer technology has a wide range of possibilities for integration in education, but it is also true that access to such possibilities is strongly determined by the infrastructure available. In this study feasibility was favored by two main factors, namely, the fact that the center where this study was conducted owns a basic multimedia facility. At this facility a group of both pre and in-service teachers work as a liaison between other in-service teachers and their students when it comes to both technological and pedagogical support. Given the above, the researcher had an advantageous head start as students could be assisted on a one-on-one basis in case of failure to accomplish their new computer-mediated assignments due to either technical or computer literacy issues. Based on this experience, it was observed that feasibility not only would relate to how much one can do in terms of integrating technology in the language classroom, but also how much support a teacher can obtain from an institution considering the inclusion of computer technology. Consequently, the inclusion of technology and its success may not necessarily be a unique-teacher's responsibility, but a threefold collaborative process among teachers, students and institutions.

Exploring this threefold collaborative process begins with teachers as the main actors. As pointed out by Ertmer (2005), technology integration does not merely depend on generous investments in infrastructure, but also on understanding teachers' beliefs and how these beliefs have an impact either on the success or failure of implementing computer technology in education as reported by Windschilt and Sahl (2002). As a result, administrators should be aware of the existence of models as "The Unified Theory of Acceptance and Use of Technology" (UTAUT) introduced by Venkatesh, Morris, Gordon, Davis, and Davis (2007) regarding the use of computers at the corporate level. This study revealed significant sociolinguistic influence in the use of computers as well as personal factors such as the extent to which individuals can identify themselves with the use of computers and alter their personal belief system, and not simply fall into institutional obedience.

The second factor to consider in a technology collaborative integration process is students. In this study, students' beliefs and attitudes toward the use of technology may have been highly favored by the fact that all of these students reported having had previous contact with a computer and familiarity using some Internet tools. Despite this previous contact, familiarity and constant support in class, obstacles arose as students began to set up their own personal website in Yahoo 360, and at the end of the study a significant percentage of these students reported not to be willing to continue using Yahoo 360 again. Surprisingly enough, at the end of their English course, most students reported having some interest in using Yahoo 360. This may indicate that the use of virtual communities at first hand may have seemed intimidating for students, but as these students were given constant support, their initial beliefs and attitudes could have changed regarding the use of Yahoo 360. Of course, other variables could have triggered this reaction bearing in mind that students reported having both the desire and the need to study English. In other words, an unexplored mixture of intrinsic and extrinsic motivation could have played a decisive role in students' attitudes toward the use of Internet tools, even if such tools appeared to be overwhelming when first introduced. 
The third factor to attend to is the role of institutions. One could infer, based on the results of this study that computer technology in the language classroom does not simply need to be initiated but also supported by an institution on an ongoing basis. Such support implies access to physical infrastructure as well as human support. In light of this, pre-service teachers may be a top-notch choice in providing the human support referred to here since these teachers are also the ones, who will be exploring their different beliefs about using computer technology for potential change based on a real-life problem solving exercise. That being said, it is not intended by any means that in-service teachers be excluded from the proposed human support units referred to in this document, rather, what is advocated here is that by encouraging pre-service teachers' participation in such human support units may lead to get to Albion's (2002) problem-solving approach aimed at having pre-service teachers reflect on their beliefs about using technology in their classes, and one may add, while assisting those in service.

Aside from the process of technology integration, I will revisit the principle of time mentioned earlier. Similar to other EFL classes, students' authentic contact with the target language and language practice were limited only to in-class activities. Therefore, integrating extra material represented a challenge. Fortunately, as explained by Butler-Pascoe and Wiburg (2003), technology allows for either synchronous (e.g. real time chats, videoconferencing) or asynchronous communication (e.g. E-mail, blogs). These two types of communication became an asset for this study, particularly, asynchronous communication because it permits both teachers and students to communicate outside the classroom resulting not only in authentic communication exchanges, but also invaluable contact with the target language. This idea of technology allowing for contact with the target language outside the classroom is reinforced and desired when students are enrolled in a program in which contact with the target language may well be limited to only classtime. While it was not within the scope of this study to inquire how beneficial extra contact with a target language is represented in foreign language learning by computer-mediated communication, important questions inevitably arise for educators as to how computer technology can finally solve the immense gap students experience when learning a language isolated from its natural context, and to some extent, how computer technology could simulate such context bearing in mind the existence of online applications such as Virtual Worlds or Second Life. If computer technology could simulate a context for language learning, important advancements could be made in regards to the efficiency of what is notoriously known as a long-life learning process that many times ends up in frustration for some. Once again computer technology could fulfill its promise of efficiency and productivity not only in the corporate world but also in language education.

Finally, the two principles yet to be discussed, are user-friendliness and students' likes and dislikes. These two principles played a key role in this study based on the assumption that strategically combining these two would result in students' preference for the technology-task proposed without much trouble. In fact, the students' reactions observed in this study appeared to have resulted from this strategic combination. Nevertheless, similar implementation of computer technology in foreign language instruction should not ignore the dichotomy of computer technology being an astounding tool in education, but also being a factor of major distraction as noted by Windschitl and Sahl (2002). In this study, technology was identified as a distraction during the instant-messaging sessions that students were assigned. A way of solving this problem was by constantly monitoring students' work and reminding them of the task objectives that at times appeared to be obscured by the off-task conversations students attempted to establish with their acquaintances. From this experience, one may suggest that caution must be used when students' likes and dislikes are met by presenting content in an appealing manner since language objectives may be easily overshadowed leading to the implementation of an important resource in education to failure due to lack of task-accomplishment control mechanisms. 


\section{Conclusions}

The study reviewed in this paper was an exploratory process of integrating computer-mediated-tasks in two EFL classes for the first time. The results of this study provided a general picture of what appeared to be a group of motivated instructors and students and how this combination set up a context adjustable to the use of computer technology in a foreign language class over a one-semester period. The results obtained in this study appear to be positive in that students' perceptions and willingness to use computer technology in their language classes was for the most part positive. Nevertheless, a small number of students, as shown in the results section expressed negative feelings towards the use of computer technology, specially, when using Yahoo 360. Regarding this discrepancy, Chapelle and Jamieson's (1986) argument about learning styles playing a crucial role in students' success in using computer technology may explain why some of the participants in this study did not perceive the use of computer technology and English positively. In fact, the researcher chose Internet tools based only on students' likes and dislikes, but dismissed their learning styles. Further research could clear up this unresolved question by possibly understanding students' learning styles and how these cognitive theories could influence students' preference for traditional activities over technology-based ones. For example, in this study when students were asked about whether it was easier for them to communicate by means of a computer or by interacting directly with their classmates, results were rather inconclusive as students' answers did not differ significantly between these two options. That being said, further research could also aid in the identification of the ways in which computer technology could reach those students who have a preference for more human-oriented communication instead of computer-mediated communication, and if the use of computer technology is necessary for these individuals or not. By the same token, it would be worth exploring what other reasons aside from language planning production and lowering anxiety could be behind those students who prefer computermediated communication instead of face-to-face communication.
Supporting the discussion above, future research could also assist in understanding the interaction of adolescents' formation of identity and how the promise of computer technology would be tailormade by the use of entertaining yet language-teaching adaptable technology and Internet applications that allow adolescents to express themselves while overcoming many of the challenges typical of this developmental stage such as reluctance to speak a second language or interact with other individuals. As shown in the results section, many students in this study found the use of virtual communities as a means of expressing themselves and overall speaking as a means for communication and self-expression. These ideas inevitably lead to believe that these students may have perceived themselves as members of a nascent community of practice(Lave \& Wagner, 1991) that they identify themselves easier with virtually than in real life. If this association were true, further research could explore the ways in which adolescents feel they are part of these communities of practice and how such affiliation could revolutionize the role of English not only as a medium for communication, but also as a life style.

Another interesting finding in this study was students' report on intrapersonal communication strategies while chatting in English. This is an intriguing area for further study bearing in mind that during teenage years reluctance to speak a foreign language may be caused by the lack of a solid identity in individuals, and how computer-mediated communication becomes an alternative path for communication and for foreign language enhanced acquisition. Nevertheless, more questions remain as to the quality of output that students produce while being engaged in computer-mediated communication.

All in all, computer technology integration in language instruction as planned in this study became a challenging yet rewarding experience for both students and instructors. Based on the experience drawn from this study, the researcher concluded that technology in this study did fulfill many of its theoretical promises and proved to be versatile and useful if mixed with creativity, support 
and willingness to learn and be challenged. While the results are not clear-cut and conclusive, they do shed light on the need for further research in the

\section{Bibliography}

Albion, P. \& Ertmer, P. (2002). Beyond the foundations: the role of vision and belief in teacher's preparation for integration of technology. Techtrends, 46, 34-38.

Butler-Pascoe, M. E. \& Wiburg, K. (2003). Technology and teaching English language learners. New York: Allyn \& Bacon.

Chapelle, C. (2003). English language learning and technology. Philadelphia: John Benjamins Publishing Company.

Chapelle, C. \& Jamieson, J. (1986). Computer-assisted language learning as a predictor of success in acquiring English as a second language. TESOL Quarterly 20, 27-46.

Ertmer, P. A. (2005). Teacher pedagogical beliefs: the final frontier in our quest for technology integration? Educational Technology Research and Development, $53,25-39$.

Gardner, R. C. (1985). Social psychology and second language learning. The role of attitudes and motivation. London: Edward Arnold.

Lave, J. \& Wenger, E. (1991). Situated learning: legitimate peripheral participation. New York: Cambridge University Press.

Lerner, R. M., Easterbrooks, M. A., Mistry, J. \& Weiner I. B. (Eds.). (2003). Handbook of psychology: Vol. 6. Developmental psychology. New York, NY: Wiley. revolutionary field of computer-mediated communication and language learning.

Norton Pierce, B. (2000). Identity and language learning: gender, ethnicity and educational change. London: Longman.

Reed, J. H., Scharllert D. L., Beth, A. D. \& Woodruff, A. L. (2004). Motivated reader, engaged writer: the role of motivation in the literate acts of adolescents. In J. Tamara \& J. Dole (Eds.), Adolescent literacy research and practice (251-282). New York: The Guilford Press.

Roed, J. (2003). Language learner behavior in a virtual environment. Computer assisted language learning, $16,155-172$.

Venkatesh, V., Morris, M. G., Davis G. B. \& Davis F. D. (2003). User acceptance of information technology: toward a unified view. MIS Quarterly, 27, 425-478.

Warschauer, M. \& Healey, D. (1998). Computer and language learning: an overview. Language Teaching, 31, 57-71.

Windschitl, M. \& Sahl, K. (2002). Tracing teachers' use of technology in a laptop computer school: the interplay of teacher beliefs, social dynamics, and institutional culture. American Educational Research Journal, 39, 165-205.

Wolsey, T. D., \& Grisham, D. L. (2007). Adolescents and the new literacies: writing engagement. Action in Teacher Education, 29, 29-38. 